\title{
ПЕДАГОГІЧНИЙ СУПРОВІД ФОРМУВАННЯ ГОТОВНОСТІ СТУДЕНТІВ ЗВО ДО НАУКОВО-ДОСЛІДНИЦЬКОЇ ДІЯЛЬНОСТІ НА ЗАСАДАХ АКАДЕМІЧНОЇ ДОБРОЧЕСНОСТІ
}

\author{
Варава I. М. \\ старший викладач кафедри іноземних мов \\ Харківський наџіональний університет міського господарства імені О. М. Бекетова \\ вул. Маршала Бажанова, 17, Харків, Украӥна \\ orcid.org/0000-0002-7374-5682 \\ varavva.irina@gmail.com
}

\author{
Ключові слова: академічна \\ доброчесність; науково- \\ дослідницька діяльність \\ студентів, педагогічний \\ супровід; навчальна \\ технологія; студенти \\ закладів вищчої освіти.
}

\begin{abstract}
У статті розглянуто особливості реалізації педагогічного супроводу формування готовностістудентів 3ВО донауково-дослідницькоїдіяльності на засадах академічної доброчесності. Звертається увага, що для сучасного випускника 3ВО не менш актуальною, ніж наявність глибоких предметних знань і практичних умінь і навичок, є сформованість у нього готовності до науково-дослідницької діяльності, під час здійснення якої найважливіша умова - це дотримання принципів академічної доброчесності. Вивчено наукові підходи вітчизняних та зарубіжних учених до цього питання, підкреслюється їхня загальна позиція, що життя та діяльність ученого (у тому числі вченого-початківця, студента-дослідника) повинні відповідати стандартам і традиціям академічної доброчесності, щоби протидіяти суттєвій деформації освітнього середовища. Аргументується вибір як основи педагогічного супроводу педагогічної технології формування готовності студентів 3ВО до науково-дослідницької діяльності на засадах академічної доброчесності. Наведено опис змісту та основних елементів складників технології формування готовності студентів закладів вищої освіти до науково-дослідницької діяльності на засадах академічної доброчесності: описово-цільового, наукознавчого, процесуально-дієвого, оцінно-рефлексивного. Наведено комплекс заходів, що були реалізовані у процесі педагогічного супроводу формування готовності студентів 3ВО до науково-дослідницької діяльності, таких як: мотивація студентів до наукового пізнання, самовиявлення у різних видах науково-дослідницької діяльності; розвиток інтересу до змісту дисципліни; оволодіння студентами знаннями, що дають цілісне уявлення наукову комунікацію, правила виконання науково-дослідних робіт і принципи академічної доброчесності; роз'яснення студентам цілей академічної сумлінності, причин та видів порушень; розроблення та прийняття студентами «Кодексу наукової етики»; підтримка їх взаємодії із суб'єктами наукової та професійної спільноти тощо. Робиться висновок, що презентована у статті педагогічна технологія $є$ орієнтиром для розвитку методичної компетентності викладачів у процесі педагогічного супроводу формування готовності студентів 3ВО до науково-дослідницької діяльності на засадах академічної доброчесності і дає змогу впроваджувати й удосконалювати цей процес на практиці.
\end{abstract}




\title{
PEDAGOGICAL SUPPORT IN FORMATION OF UNIVERSITY STUDENTS' ABILITY TO CONDUCT SCIENTIFIC RESEARCH ON THE BASIS OF ACADEMIC INTEGRITY
}

\author{
Varava I. M. \\ Senior Lecturer at the Department of Language Training \\ O. M. Beketov National University of Urban Economy in Kharkiv \\ Marshal Bazhanov str., 17, Kharkiv, Ukraine \\ orcid.org/0000-0002-7374-5682 \\ varavva.irina@gmail.com
}

Key words: academic integrity; scientific research of students, pedagogical support; educational technology; students of higher education institutions.
The article deals with the specific features of pedagogical support in formation of university students' ability to conduct scientific research on the basis of academic integrity. Attention is drawn to the fact that for a modern graduate of higher educational establishment the ability to conduct scientific research is as much important as obtaining deep subject knowledge and practical skills, and the most important condition for conducting research activities is compliance with the principles of academic integrity. The scientific approaches of national and foreign scientists to this issue have been studied, their general viewpoint has been emphasized in the article. The basic point is that the life and activity of a scientist (including a young scientist, a student who is conducting research) must meet the standards and traditions of academic integrity to counteract significant deformation of the educational environment. The reasons for choosing of pedagogical technology in formation of university students' ability to conduct scientific research on the basis of academic integrity as the grounds of pedagogical support have been given.

The description of the content and main elements of the technology in formation of university students' ability to conduct scientific research on the basis of academic integrity has been given: descriptive and target-oriented, scientific, procedural and practical, evaluative and reflective.

A set of measures implemented in the process of pedagogical support in formation of university students' ability to conduct scientific research has been presented: motivation of students for scientific knowledge, self-discovery in various types of research activities; development of interest in the subject; mastery of knowledge that gives a holistic view of scientific communication, the rules of research and the principles of academic integrity; explaining to students the goals of academic integrity, causes and types of violations; development and adoption by students of the "Code of Scientific Ethics"; support of their interaction with the fellows of the scientific and professional community, etc.

It is concluded that the pedagogical technology presented in the article is a reference point for the development of methodological competence of teachers in the process of pedagogical support in formation of university students' ability to conduct scientific research on the basis of academic integrity and allows to implement and to improve this process in practical terms.
Постановка проблеми. Активні процеси, що відбуваються у сучасній економічній, політичній, соціальній сферах світового життя, неминуче зачіпають і освіту. Вища професійна освіта України переживає багатовекторний процес перетворень, однією $з$ найважливіших цілей якого $є$ реалізація компетентнісного підходу, комплексна підготовка фахівця, здатного до професійного росту, саморозвитку, готового до здійснення актуальних наукових досліджень у певній галузі знань, що теж сприяє набуттю затребуваних ринком праці компетенцій. Для сучасного випускника закладу вищої освіти вже недостатньою $€$ наявність тільки глибоких предметних знань і практичних умінь і навичок. Не менш актуальною є сьогодні сформованість готовності студента до науково-дослідницької діяльності, але найважливішим під час ії здійснення $€$ дотримання принципів академічної доброчесності. 
Аналіз останніх досліджень. За результатами огляду сучасних наукових публікацій можна констатувати, що питання формування готовності студентів ЗВО до науково-дослідницької діяльності досліджувалося вченими-педагогами здебільшого у контексті іiї впливу на формування у студентів професійних компетенцій та подальшої конкурентоспроможності випускників на ринку праці. Зокрема, цей аспект проблеми викладено у роботах В. Бєляєва, Т. Гладкої, О. Дроніної, О. Сгорової, О. Савченко, Н. Сидорчук, Л. Ткачук, І. Фролової та інших. Із цих позицій науково-дослідницька діяльність студентів розглядається науковцями як засіб їхньої професійної підготовки, що відрізняється всіма характеристиками навчально-пізнавальної роботи (передбачає вивчення певного об'єкта педагогічної дійсності у процесі вирішення пізнавального завдання проблемного характеру) і водночас має ознаки творчої діяльності, актуалізує креативні можливості особистості в аспекті вироблення власного бачення шляхів розв'язання проблемного завдання [1].

Академічна доброчесність як основа науково-дослідної діяльності вченого та наслідки ії недотримання $\epsilon$ сьогодні як ніколи злободенним питанням для української науки. Адже недопустимою $є$ ситуація, коли «наукові роботи (від курсових до докторських) виконуються на замовлення, студентські роботи передаються від курсу до курсу лише зі зміненими титульними сторінками, у наукових текстах перефразовують чужі думки та видають за власні без посилання на їх справжнього автора, коли метою наукового дослідження не $\epsilon$ нове наукове знання» [2, с. 9].

Питання академічної доброчесності позиціонується як визначальний принцип наукової діяльності у роботах таких учених, як А. Артюхов, Р. Барбато, Р. Безус, Дж. Бейлі, М. Гарфінкель, М. Дойчик, Ю. Спіфанова, Ю. Кращенко, А. Колдовський, М. Рой, В. Сацик, Т. Серьогіна, Н. Сорокіна, Є. Стадний, О. Стрямець тощо. У своїх працях ці науковці висловлюють думку, що життя та діяльність ученого (у тому числі вченого-початківця, студента-дослідника) повинні відповідати стандартам і традиціям академічної доброчесності, щоби протидіяти суттєвій деформації освітнього середовища, робити його прозорим та здатним надавати супротив зовнішнім тискам, відстоювати власні позиції. Але, незважаючи на те, що впровадження принципів академічної доброчесності в освітньому та науковому середовищі $є$ сьогодні досить актуальною проблемою, особливості педагогічного супроводу формування готовності студентів до науково-дослідницької діяльності на основі цих принципів ще досить рідко стають предметом уваги науковців.

3 огляду на вищевикладене, метою статті $\epsilon$ аналіз сутності провідних дефініцій досліджу- ваної проблеми; розгляд принципів створення та розкриття складників відповідної педагогічної технології; презентація головних шляхів формування у студентів закладів вищої освіти готовності до науково-дослідної діяльності на засадах академічної доброчесності.

Виклад основного матеріалу дослідження. У статті 42 Закону України про освіту (2017 р.) академічна доброчесність визначається як «сукупність етичних принципів та визначених законом правил, якими мають керуватися учасники освітнього процесу під час навчання, викладання та провадження наукової (творчої) діяльності 3 метою забезпечення довіри до результатів навчання та/або наукових (творчих) досягнень» [3]. Обов'язковим для дотримання академічної доброчесності у науково-дослідницькій діяльності здобувачів освіти $є$ «посилання на джерела інформації у разі використання ідей, розробок, тверджень, відомостей; дотримання норм законодавства про авторське право і суміжні права; надання достовірної інформації про результати власної навчальної (наукової, творчої) діяльності, використані методики досліджень і джерела інформації» [3].

Засади академічної доброчесності передбачають недопущення академічного плагіату, самоплагіату, фабрикації, фальсифікації даних чи фактів, списування у процесі власної освітньої (наукової, творчої) діяльності. Формування у студентів закладів вищої освіти готовності до науково-дослідної діяльності повинно здійснюватися на основі дотримання принципів академічної доброчесності.

Важливою тезою, що становила основу нашого педагогічного супроводу формування готовності студентів 3ВО до науково-дослідницької діяльності на засадах академічної доброчесності, стала ідея М. Князян щодо систематичності впровадження науково-дослідницької діяльності. Так, науковець стверджує, що найкращим способом надання обізнаності студентам із наукового знання та їх мотивації до науково-дослідницької діяльності $\epsilon$ організація розвитку їх наукового пізнання у трифазовому періоді: на рівні препаративної фази - ознайомлення студентів із найважливішими характеристиками наукового дослідження (інтраструктурним аналізом категорій наукової галузі, укладанням банку ключових дефініцій, аналізом наукових підходів та дискусій щодо актуальної проблеми наукового пізнання), а також із таксономією цілей наукового дослідження; на рівні модифікаційної фази - визначення структури змісту тексту із відповідним упорядкуванням понять; створення понятійного апарату дослідження; вироблення концептуальних конструктів; написання аналітичних есе; на рівні креативної фази - утворення концептуальної синтез-схеми 
дослідження, підготовка авторської системи науково-дослідницьких заходів, самодіагностика поточних наукових досягнень [4, с. 109-111].

Основою педагогічного супроводу ми вважаємо розроблення і впровадження відповідної педагогічної технології. Технологію формування готовності студентів закладів вищої освіти до науково-дослідницької діяльності на засадах академічної доброчесності розуміємо як сукупність взаємодії викладачів 3ВО, спрямовану на становлення і розвиток особистості студента як майбутнього науковця та (або) фахівця, що керується у власній діяльності принципами доброчесності, а також систему цілей, змісту, методів, форм, засобів, способів та прийомів навчання, видів контролю і корекції, що поетапно впроваджуються у навчальний процес 3ВО та гарантують досягнення кінцевого результату.

Складниками технології формування готовності студентів закладів вищої освіти до науково-дослідницької діяльності на засадах академічної доброчесності нами визначено: описово-цільовий, наукознавчий, процесуально-дієвий, оцінно-рефлексивний складники.

Головними елементами описово-цільового складника технології є мета (формування готовності студентів ЗВО до науково-дослідницької діяльності на засадах академічної доброчесності), завдання (мотивація студентів до наукового пізнання, спроб самовиявлення у різних видах наукових продуктів; оволодіння знаннями, що дають цілісне уявлення про наукову діяльність, науковий текст, наукову комунікацію, принципи академічної доброчесності; формування умінь наукової діяльності на основі дотримання принципів академічної доброчесності; забезпечення можливостей наукового самовиявлення для студентів у різних видах взаємодії із суб' єктами наукової та професійної спільноти), компоненти (мотиваційно-рефлексивний, когнітивно-комунікативний, деонтологічний, організаційний, оцінно-результативний) та попередня діагностика готовності студентів до науково-дослідницької діяльності (діагностика сформованості мотивації до наукової діяльності, рівня наукових знань та умінь, спрямованості на активність у наукових комунікаціях, компетентності щодо деонтологічної складової частини наукової діяльності).

У змісті наукознавчого складника нами означено методологічні засади та принципи реалізації технології формування готовності студентів 3ВО до науково-дослідницької діяльності на засадах академічної доброчесності.

Основним підходом, на якому базується запропонована нами технологія, визначено особистісно-діяльнісний, який передбачає, що засобом навчання і розвитку особистості стає активна творча, професійно спрямована діяльність студента, у процесі якої він не стільки засвоює готові знання, уміння й навички, скільки оволодіває способами цього засвоєння, мислення та діяльності, розвиває власний творчий потенціал, формує професійно значущі якості. Відзначимо також важливу роль системного, ресурсного (урахування внутрішнього потенціалу особистості, який разом із мотивацією дає змогу досягти якісної результативності у наукових проєктах, дослідженнях та ïx затребуваності суспільством) та деонтологічного (забезпечення норм моралі і права у науковій діяльності, обов'язку і відповідальності науковця перед суспільством за авторство наукової ідеї, концепції, продукту) методологічних підходів, що становили основу цісї технології. Розроблення технології формування готовності студентів до науково-дослідницької діяльності на засадах академічної доброчесності засновувалося на принципах наступності і перспективності, системності, нарощування складності, активності, суб' єктності та доброчесності.

Процесуально-дієвий складник включав зміст підготовки (оновлений зміст навчальних дисциплін) та форми виявлення науково-дослідницької діяльності (лекції, семінарські, практичні заняття, конкурсні заходи, апробаційно-презентаційні активності, колективні наукові продукти, створення та публікацію наукових статей, науково-популярну комунікацію (зокрема, волонтерство)). Основними дисциплінами, що були використані нами як базові для реалізації запропонованої нами педагогічної технології, було вибрано дисципліни суспільно-гуманітарного циклу: «Українська мова за професійним спрямуванням», «Іноземна мова», «Основи права», «Основи наукового дослідження» (дисципліна викладалася перед створенням студентами курсової роботи за фахом). Під час проведення занять із цих дисциплін викладачами здійснювалася підготовка студентів до науково-дослідницької діяльності, закладалися основи понятійного апарату наукового дискурсу, структури різного виду наукових продуктів. Експериментальне дослідження проводилося нами на базі студентів архітектурного профілю підготовки студентів Харківського національного університету міського господарства імені О.М. Бекетова, отже, 3 метою реалізації означеної педагогічної технології ми задіяли і дисципліни фахового спрямування - «Історія архітектури, містобудування та мистецтва», «Архітектурне проектування» (курсова), «Архітектурне моделювання», «Основи районного планування», «Урбаністика», позанавчальну наукову діяльність тощо.

В оцінно-рефлексивному складнику визначено критеріально-показниковий апарат технології та наведено рефлексію результатів іiі впровадження. 
Під рефлексією розуміємо «здатність людини до самоспостереження, самопізнання, самоаналізу та усвідомлення зовнішньої оцінки особистісних особливостей іншими людьми, результатом чого $є$ критичне оцінювання власних дій, досягнень, ресурсів, особистісних якостей та, за необхідності, їх корекція» [5, с. 102]. Звернемо увагу, що повна якісна оцінка реалізації запропонованої нами технології має спиратися на подвійну рефлексію (тобто рефлексію з погляду суб'єктів викладачів, які реалізовували цю технологію, та об'єктів - студентів, які були задіяні у iï реалізаціi). Отже, рефлексія студентів рівня особистої готовності до науково-дослідницької діяльності мала організовуватись у процесі аналізу результатів їхньоъ діяльності, у межах якого студентів спрямовували до самоаналізу та самооцінки.

Для оцінки ефективності впровадження технології нами визначено критеріально-показниковий апарат, що надає можливість вимірювання зрушень у рівні сформованості готовності студентів 3ВО до науково-дослідницької діяльності на засадах академічної доброчесності. Такими критеріями нами визначено мотиваційно-рефлексивний (показники: мотивація до наукової діяльності, мотивація до успіху, рефлективність, адекватна самооцінка, рівень домагань); когнітивно-діяльнісний (показники: наукові знання, активність у комунікації, організованість); деонтологічний (показники: правові знання, академічна доброчесність). Для вимірювання якісних зрушень кожного із запропонованих показників вибрано такі методики: методика дослідження мотивації до успіху (уникнення невдач) А. Реана; методика дослідження рівня рефлективності А. Карпова; методика дослідження рівня самооцінки С. Будассі та рівня домагань Й. Шварцландера, а також оригінальний опитувальник щодо мотивації студентів до наукової діяльності; вимірювання наукових знань згідно із змістом контрольних питань програми дисципліни «Основи наукового дослідження»; дослідження сформованості умінь активної комунікації та організованості за опитувальником КОС-2; тест «Авторське право та суміжні права» Луцького національного технічного університету, оригінальний опитувальник «Академічна доброчесність».

Результатом реалізації технології є сформованість готовності студентів закладів вищої освіти до науково-дослідницької діяльності на засадах академічної доброчесності шляхом запропонованих форм та способів педагогічного впливу.

У процесі реалізації педагогічного супроводу формування готовності студентів 3ВО до науково-дослідницької діяльності ми вважали правильним вести боротьбу не лише з окремими проявами академічної недоброчесності, а насамперед із причинами, що породжують у сучасному освітньо-науковому середовищі сприятливі умови для iii наявності. На цьому шляху ефективним виявилося проведення певного комплексу заходів:

- мотивація студентів до наукового пізнання, самовиявлення у різних видах науково-дослідницької діяльності;

- розвиток інтересу до змісту дисципліни (посилення іï практичної спрямованості, підкреслення зв'язку змісту навчальних завдань із конкретними професійними завданнями за профілем підготовки студентів);

- оволодіння студентами знаннями, що дають цілісне уявлення про наукову діяльність, науковий текст, наукову комунікацію, правила виконання науково-дослідних робіт і принципи академічної доброчесності;

- роз'яснення студентам цілей академічної сумлінності, причин та видів порушень, можливих наслідків і способів боротьби з ними;

- розроблення та прийняття студентами «Кодексу наукової етики», що просуває такі цінності, як професіоналізм, щирість, чесність і відкритість, відповідальність і сумлінність, повага до честі і гідності особистості, підтримка ділової репутації навчального закладу, і містить зобов'язання про дотримання загальноприйнятих морально-етичних норм і недопущення проявів академічної несумлінності;

- розвиток творчого підходу до навчальної діяльності, забезпечення можливостей виявлення наукової креативності, відповідальності за наукові продукти, підтримка дослідницької, творчої активності студентів, взаємодії із суб'єктами наукової та професійної спільноти.

Висновки. Вважаємо, що педагогічний супровід формування готовності студентів ЗВО до науково-дослідницької діяльності на засадах академічної доброчесності полягає у забезпеченні реалізації комплексу складників відповідної педагогічної технології для повноцінного здійснення цього процесу: описово-цільового, наукознавчого, процесуально-дієвого, оцінно-рефлексивного. Проведене нами дослідження дало змогу зробити висновок, що презентована у статті педагогічна технологія $є$ орієнтиром для розвитку методичної компетентності викладачів у процесі педагогічного супроводу формування готовності студентів ЗВО до науково-дослідницької діяльності на засадах академічної доброчесності і дає змогу впроваджувати й удосконалювати цей процес на практиці.

Перспективу подальших досліджень вбачаємо у розробленні і практичних методів, і прийомів формування готовності студентів ЗВО до науково-дослідницької діяльності на засадах академічної доброчесності. 


\section{ЛІТЕРАТУРА}

1. Фролова І.В. Науково-дослідницька діяльність студентів - передумова випереджувального саморозвитку фахівця. Наукові записки Ніжинського державного університету імені М. Гоголя. Сер.: Психолого-педагогічні науки. 2012. № 7. URL: http://nbuv.gov.ua/UJRN/Nzspp_2012_7_46

2. Академічна доброчесність: проблеми дотримання та пріоритети поширення серед молодих учених : кол. моногр. / за заг. ред. Н.Г. Сорокіної, А.Є. Артюхова, І.О. Дегтярьової. Дніпро : ДРІДУ НАДУ, 2017. 169 с.

3. Про освіту: Закон України від 05.09.2017 № 2145-VIII. Відомості Верховної Ради (ВВР). 2018. № 38-39. Ст. 42.

4. Князян М.О. Науково-дослідна діяльність як засіб формування критичного мислення студентів. Науковий вісник Південноукраӥнського національного педагогічного університету ім. К. Д. Ушинського. 2011. № 3-4. С. 107-113.

5. Резван О.О. Теоретико-методичні засади формування професійно-рефлексивної позиції майбутніх фахівців автомобільно-дорожньої галузі: дис. ... д-ра пед. наук : 13.00 .04 «Теорія і методика професійної освіти». Харків, 2016. 457 с.

\section{REFERENCES}

1. Frolova, I.V. (2012). Naukovo-doslidnytska diialnist studentiv [Research activity of students is a prerequisite for advanced self-development of a specialist] Naukovi zapysky Nizhynskoho derzhavnoho universytetu imeni M. Hoholia. Seriia: Psykholoho-pedahohichni nauky, Vol. 7. URL: http://nbuv.gov.ua/ UJRN/Nzspp_2012_7_46

2. Artiukhov, A., Bezus, R., Vasylieva, T., Dehtiarova, I., Iepifanova, Y., Krashchenko, Y., Sorokina, N. Tolstanova, H. (2017). Akademichna dobrochesnist: problemy dotrymannia ta priorytety poshyrennia seredmolodykh vchenykh : kolektyvna monohrafiia. Dnipro : DRIDU NADU.

3. Pro Osvitu: Zakon Ukrainy 2017, № 2145-VIII. stattia 42 (2018).

4. Kniazian, M.O. (2011). Naukovo-doslidna diialnist yak zasib formuvannia krytychnoho myslennia studentiv [Research activity as a means of forming students' critical thinking] Naukovyi visnyk Pivdennoukrainskoho natsionalnoho pedahohichnoho universytetu imeni K. D. Ushynskoho. Vol. 3-4. P. 107-113.

5. Rezvan, O.O. (2016) Teoretyko-metodychni zasady formuvannia profesiino-refleksyvnoi pozytsii maibutnikh fakhivtsiv avtomobilno-dorozhnoi haluzi. (Dysertatsiia doktora pedahohichnykh nauk) Kharkiv National Pedagogical University named after G.S. Skovoroda, Kharkiv. 